Article

\title{
Stimulatory Effect of Silver Nanoparticles on the Growth and Flowering of Potted Oriental Lilies
}

\author{
Piotr Salachna ${ }^{1, * \mathbb{C}}$, Andżelika Byczyńska ${ }^{1, *}$, Agnieszka Zawadzińska ${ }^{1}$, Rafał Piechocki ${ }^{1}$ \\ and Małgorzata Mizielińska ${ }^{2}$ \\ 1 Department of Horticulture, West Pomeranian University of Technology, 3 Papieża Pawła VI Str., \\ 71-459 Szczecin, Poland; agnieszka.zawadzinska@zut.edu.pl (A.Z.); rafal.piechocki@zut.edu.pl (R.P.) \\ 2 Center of Bioimmobilisation and Innovative Packaging Materials, West Pomeranian University of \\ Technology, 35 Janickiego Str., 71-270 Szczecin, Poland; malgorzata.mizielinska@zut.edu.pl \\ * Correspondence: piotr.salachna@zut.edu.pl (P.S); andzelika.woskowiak@zut.edu.pl (A.B.); \\ Tel.: +48-91-4496-359 (P.S \& A.B.)
}

Received: 29 July 2019; Accepted: 29 September 2019; Published: 3 October 2019

\begin{abstract}
Nanoparticles exhibit unique biological activities and may serve as novel plant growth stimulators. This research consisted of a two-year pot experiment designed to find out if silver nanoparticles (AgNPs) might be used in the cultivation of Oriental lilies. In the first year, we evaluated the effects of various concentrations of $\operatorname{AgNPs}(0,25,50,100$, and $150 \mathrm{ppm})$ and their application methods (pre-planting bulb soaks, foliar sprays, and substrate drenches) on the growth and flowering of Lilium cv. Mona Lisa. In the second year, we evaluated the effects of soaking the bulbs of cv. Little John in the same concentration of AgNP solution on plant morphological features, leaf content of photosynthetic pigments, basic macronutrients, and complex biomolecules with the use of the Fourier-transform infrared spectroscopy (FTIR). Soaking the bulbs in a nanoparticle solution turned out to be the most effective strategy for growth and flowering promotion. AgNPs stimulated plant growth, as manifested by enhanced accumulation of leaf and bulb biomass and accelerated flowering. Moreover, plants treated with silver nanoparticles showed higher leaf greenness index, formed more flowers, and flowered longer. At $100 \mathrm{ppm}$ AgNPs, the leaves accumulated the highest content of chlorophyll a, chlorophyll b, and carotenoids, and were the richest in potassium, calcium, and sulfur. The FTIR spectra did not show any changes in absorbance intensity and chemical composition in the leaves from AgNP-treated bulbs.
\end{abstract}

Keywords: Lilium; nanosilver; biostimulators; ornamentals; pigments; nutrients; biomacromolecule

\section{Introduction}

Advances in nanotechnology have allowed for the production of specific nanoparticles with unique properties and a wide spectrum of practical applications [1]. Nanoparticles are characterized by small size, low weight, and a high surface to volume ratio [2]. In the agriculture industry, they are increasingly being used as components of new fertilizers [3], plant protection products [4], herbicides [5], and preparations for prolonging cut flower durability [6]. Recently, nanoparticles and nanomaterials have been suggested as potential biostimulators that might improve plant propagation and growth $[7,8]$ and improve plant resistance to stress $[9,10]$. Using nanoparticles could bring numerous benefits to agriculture and horticulture, but also involves some risks related to their not yet fully recognized environmental impacts [11].

The most interesting metal nanoparticles seem to be silver nanoparticles (AgNPs), which exhibit strong biological activity [12]. They affect plants at many different levels [13,14]. Positive effects of AgNPs include stimulation of germination [15], growth invigoration [16], increased biomass 
accumulation [17], improved shoot induction and proliferation [7], or enhanced pigment content [18]. Silver nanoparticles may also show phytotoxicity, manifested by limited germination and seedling growth [19], decreased biomass of leaves and shoots [20], delay in flowering time, and inhibition of photosynthesis [21]. Therefore, further studies are needed to clarify these contradictory observations and to explain the mechanisms controlling growth stimulation or inhibition in AgNP-treated plants.

Production of potted ornamental plants is a rapidly developing area of the horticultural industry [22]. Plants with decorative flowers account for over $50 \%$ of potted plants on the market. One such plant is lily (Lilium L., Liliaceae), a globally economically important bulbous flower crop. By adding new cultivars every year, lilies are constantly growing in popularity [23]. The most attractive cultivars include oriental hybrids with large, scented flowers. These are also the most difficult to grow, mostly due to their high sensitivity to fungal pathogens $[24,25]$. The decorative value of ornamental plants may be enhanced by using growth stimulators [26,27]. However, there have been few reports on the effect of biostimulators on the yield of flowers and bulbs in lily [28,29].

This is the first study investigating the effects of different AgNP concentrations and methods of their application on the growth and flowering of potted Oriental hybrid lilies. To better understand plant response to AgNPs, we evaluated the leaf content of assimilation pigments and macronutrients and analyzed macromolecule composition using Fourier-transform infrared spectroscopy (FTIR). With the exception of our earlier research [30], no comprehensive studies have been undertaken on using metal nanoparticles as biostimulators to enhance the ornamental quality of bulbous crop plants.

\section{Materials and Methods}

\subsection{Plant Material and Growth Conditions}

The experiment was carried out between 17 March and 25 July 2015 and between 30 March and 8 August 2016 in an unheated stand-alone tunnel with area of $225 \mathrm{~m}^{2}$, covered with a double layer of plastic with a UV filter, located at the premises of West Pomeranian University of Technology in Szczecin $\left(53^{\circ} 25^{\prime} \mathrm{N}, 14^{\circ} 32^{\prime} \mathrm{E} ; 25 \mathrm{~m}\right.$ ASL. In the first year, we investigated cv. Mona Lisa, and in the second, cv. Little John. Both cultivars belong to a division of Oriental hybrids and are recommended for pot cultivation. Bulbs $12-13 \mathrm{~cm}$ in circumference were imported from Dutch breeding plantations and kept in cold storage at $6-8{ }^{\circ} \mathrm{C}$ prior to planting. The experiments included only healthy bulbs, with no spots or damage and with strong and unbroken roots.

Each year the bulbs were planted individually into $16 \mathrm{~cm}$ diameter round plastic pots with a volume of $2 \mathrm{dm}^{3}$. The pots were filled with TS1 peat substrate (Klasmann-Delimann, Germany), with a $\mathrm{pH}$ in $\mathrm{H}_{2} \mathrm{O} 5.4$ and salinity of $1.09 \mathrm{~g} \mathrm{NaCl} \mathrm{dm}^{-3}$, containing $162 \mathrm{mg} \mathrm{dm}^{-3} \mathrm{~N}^{-\mathrm{NO}_{3}}, 118 \mathrm{mg} \mathrm{dm}^{-3}$ $\mathrm{P}, 323 \mathrm{mg} \mathrm{dm}^{-3} \mathrm{~K}, 1189 \mathrm{mg} \mathrm{dm}^{-3} \mathrm{Ca}, 132 \mathrm{mg} \mathrm{dm}^{-3} \mathrm{Mg}$, and $17 \mathrm{mg} \mathrm{dm}^{-3} \mathrm{Cl}$. The plants were grown on steel tables with a density of 16 plants per $\mathrm{m}^{2}$ under a natural photoperiod, and mean air temperature in the tunnel $(2015 / 2016)$ was: March $9.9 / 9.0^{\circ} \mathrm{C}$, April $11.9 / 12.4{ }^{\circ} \mathrm{C}$, May $15.4 / 19.8{ }^{\circ} \mathrm{C}$, June $18.1 / 22.0{ }^{\circ} \mathrm{C}$, and July $21.4 / 21.3^{\circ} \mathrm{C}$.

\subsection{Treatments}

AgNPs purchased from Sigma Aldrich (particle size $<100 \mathrm{~nm}$ and surface area $5.0 \mathrm{~m}^{2} \mathrm{~g}^{-1}$ ) were dissolved in deionized water and used at the following concentrations: 0 (control), 25, 50, 100, and $150 \mathrm{ppm}$. In the first year of the study, three application methods were investigated: (I) bulb soaking in AgNP solution for $60 \mathrm{~min}$ prior to planting, (II) substrate drenches (100 mL/pot), and (III) foliar sprays ( $45 \mathrm{~mL} /$ plant). The plants were drenched or sprayed with AgNP solutions three times, i.e., 30, 40, and 50 days after planting. In the second year, AgNPs were applied only in the form of bulb soaking prior to planting. Both experiments were arranged in a randomized complete block design, and each treatment was replicated four times with 20 bulbs per treatment. 


\subsection{Growth and Flowering Characteristics}

We determined daily the number of days from bulb planting to the beginning of anthesis and flower longevity. The beginning of anthesis was assumed as the moment when one flower per plant was fully opened. Flower longevity meant the number of days from the beginning of anthesis to the opening of the last flower. The parameters measured at the beginning of anthesis included: plant height from the soil line to the uppermost part of inflorescence, number of leaves per plant, tepal length, and tepal width. Additionally, the SPAD (soil and plant analysis development) leaf greenness index was measured with a Chlorophyll Meter SPAD 502 (Minolta, Osaka, Japan) in three fully developed leaves per plant by taking three readings per leaf and calculating mean values. When the flowering ceased, we determined the number of flowers per inflorescence, fresh weight of leaves and bulbs, and the number of scales per bulb. In the second year of the experiment, we analyzed leaves harvested from the central section of the stem of three representative plants of each treatment.

\subsection{Chlorophylls and Carotenoids}

Pigment content was determined spectrophotometrically in fresh leaves (10 $\mathrm{g}$ fresh weight). To this end, discs of the same diameter $(7 \mathrm{~mm})$ were cut out with a cork borer from the central part of the leaf. The pigments were extracted with $99 \% \mathrm{~N}-\mathrm{N}$-dimethylformamide for $24 \mathrm{~h}$. Chlorophyll a, chlorophyll $\mathrm{b}$, chlorophyll $\mathrm{a}+\mathrm{b}$, and carotenoid presence were detected by reading their absorbance at 440,645, and $663 \mathrm{~nm}$ with a spectrophotometer SPEKOL 11 (Carl Zeiss Jena, Jena, Germany). The pigment content was calculated using the appropriate formulae [31,32] and has been expressed in $\mathrm{mg} \mathrm{kg}^{-1}$ fresh weight (FW).

\subsection{Macronutrient Concentration}

Fresh leaves (100 g fresh weight) were rinsed thrice with distilled water, dried at $60^{\circ} \mathrm{C}$ to dry weight, and ground. Leaf tissue samples were then microwave digested in $\mathrm{HNO}_{3}$, using closed Teflon vessels. Phosphorus $(\mathrm{P})$, potassium $(\mathrm{K})$, magnesium $(\mathrm{Mg})$, calcium $(\mathrm{Ca})$, and sulfur $\left(\mathrm{S}_{-} \mathrm{SO}_{4}\right)$ were determined using inductively coupled plasma-optical emission spectrometry ICP-OES (Optima 2000TM DV PerkinElmer, Waltham, MA, USA). Nitrogen (N) content was established with a Kjeldahl apparatus (Vapodest, Gerhardt, Germany). Leaf macronutrient content has been expressed in \% of dry weight (DW).

\subsection{Fourier-Transform Infrared Spectroscopy (FTIR) Analysis}

Fourier-transform infrared (FTIR) spectrum of dry leaf tissue ( $2 \mathrm{~g})$ was measured using a FTIR spectroscope (PerkinElmer Spectrophotometer, Spectrum 100), operated at a resolution of $4 \mathrm{~cm}^{-1}$ for four scans. Samples were ground into powder and placed directly (each one separately) at the ray-exposing stage. The spectrum recorded a wave number of $650-4000 \mathrm{~cm}^{-1}$.

\subsection{Experimental Design and Statistical Analysis}

The experiment tested two factors in the first year (five concentrations $x$ three application methods) and a single factor in the second year (five concentrations). Each biometric measurement included three similar plants from each repetition $(n=12)$. The plant material was analyzed in three independent biological replicates $(n=3)$. The results were subjected to ANOVA using Statistica Professional 13.3 package (TIBCO Software, Palo Alto, CA, USA). Tukey's test at $p \leq 0.05$ was used to assess the smallest significant differences between means. 


\section{Results}

\subsection{Impact of AgNPs on Plant Growth and Flowering}

The outcomes from the first year indicated positive effects of AgNPs on the majority of the assessed morphological parameters in lily cv. Mona Lisa (Figure 1, Tables 1 and 2). All plants treated with AgNPs clearly showed enhanced leaf fresh weight (by 23.6-50.5\%), greenness index (by 8.6-18.4\%), and bulb fresh weight (by 44.9-73.4\%), and began flowering by two or three days earlier than control plants. At 50 ppm AgNPs, the lilies grew the tallest $(48.1 \mathrm{~cm})$, produced the greatest number of leaves (27.1), and flowered for the longest time (11.4 days), and their bulbs had the greatest fresh weight (37.1 g), and formed the greatest number of scales (23.0). The tested AgNP concentrations and application methods did not significantly affect tepal length or width (Table 2).

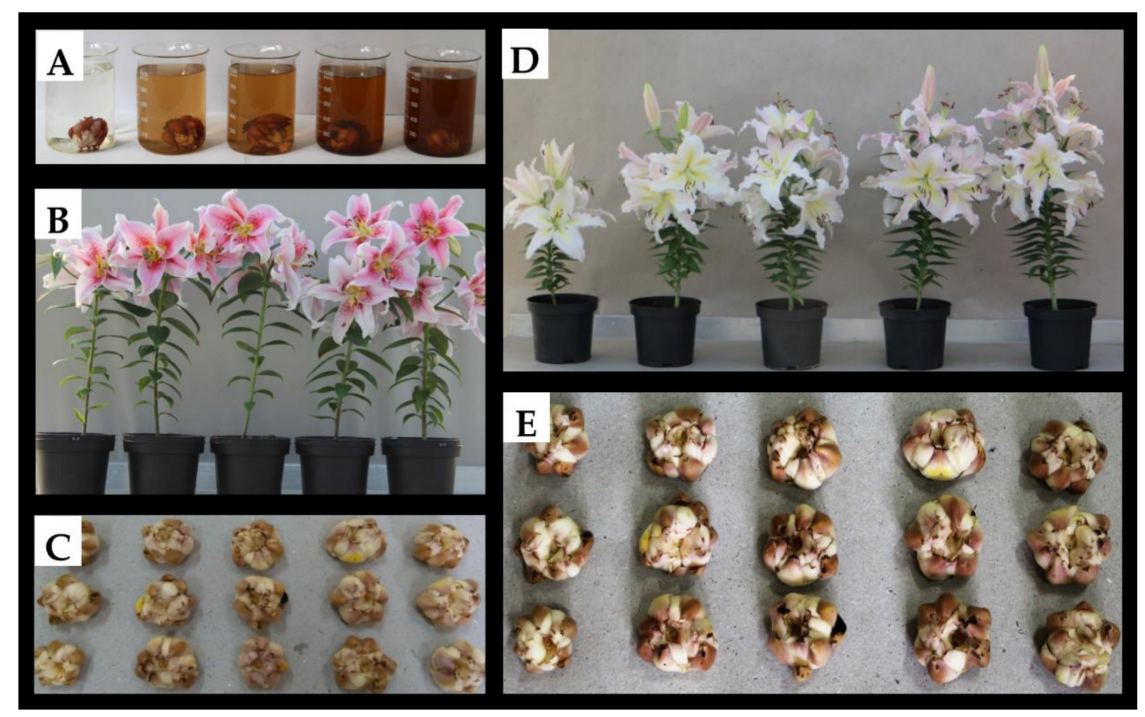

Figure 1. Effects of silver nanoparticles (AgNPs) on color change of solution (A); flowering (B) and bulb yield (C) of lily cv. Mona Lisa; flowering (D) and bulb yield (E) of lily cv. Little John after the application of AgNP pre-planting bulb soaks. Left to right: nontreated control, 25, 50, 100, and 150 ppm AgNPs.

Table 1. Main effects of silver nanoparticle (AgNP) concentration and application method on growth of lily cv. Mona Lisa. Values followed by differing letters in each column are significantly different at $p \leq 0.05$ (ANOVA and Tukey's test). ${ }^{*}, * * * * *$ : significant at $p \leq 0.05,0.01$, or 0.001 , respectively. Non-significant: ns.

\begin{tabular}{|c|c|c|c|c|c|c|}
\hline \multirow[t]{2}{*}{$\begin{array}{c}\text { AgNP } \\
\text { Treatment }\end{array}$} & \multirow[t]{2}{*}{$\begin{array}{c}\text { Plant } \\
\text { Height }(\mathrm{cm})\end{array}$} & \multirow[t]{2}{*}{$\begin{array}{l}\text { No. of Leaves } \\
\text { Per Plant }\end{array}$} & $\begin{array}{c}\text { Greenness } \\
\text { Index }\end{array}$ & $\begin{array}{c}\text { Leaf Fresh } \\
\text { Weight }\end{array}$ & \multirow[t]{2}{*}{$\begin{array}{c}\text { Bulb Fresh } \\
\text { Weight (g/Plant) }\end{array}$} & \multirow[t]{2}{*}{$\begin{array}{l}\text { No. of Scales } \\
\text { Per Bulb }\end{array}$} \\
\hline & & & (SPAD) & (g/Plant) & & \\
\hline \multicolumn{7}{|l|}{$\begin{array}{l}\text { Concentration } \\
\text { (C) }\end{array}$} \\
\hline 0 ppm & $44.7 \mathrm{~b}$ & $21.3 \mathrm{c}$ & $52.3 \mathrm{c}$ & $20.8 \mathrm{c}$ & $21.4 \mathrm{c}$ & $18.5 \mathrm{c}$ \\
\hline $25 \mathrm{ppm}$ & $45.7 \mathrm{ab}$ & $25.6 \mathrm{ab}$ & $56.8 \mathrm{~b}$ & $27.3 \mathrm{a}$ & $31.3 \mathrm{~b}$ & $19.8 \mathrm{bc}$ \\
\hline $50 \mathrm{ppm}$ & $48.1 \mathrm{a}$ & $27.1 \mathrm{a}$ & $61.5 \mathrm{a}$ & $28.1 \mathrm{a}$ & $37.1 \mathrm{a}$ & $23.0 \mathrm{a}$ \\
\hline $100 \mathrm{ppm}$ & $46.8 \mathrm{ab}$ & $23.5 \mathrm{bc}$ & $61.9 \mathrm{a}$ & $31.3 \mathrm{a}$ & $35.1 \mathrm{a}$ & $22.9 \mathrm{a}$ \\
\hline $150 \mathrm{ppm}$ & $45.6 \mathrm{ab}$ & $23.3 \mathrm{bc}$ & $61.2 \mathrm{a}$ & $25.7 \mathrm{~b}$ & $31.0 \mathrm{~b}$ & 21.1. ab \\
\hline \multicolumn{7}{|l|}{ Method (M) } \\
\hline Bulb soaks & $47.2 \mathrm{a}$ & $26.9 \mathrm{a}$ & $61.2 \mathrm{a}$ & $28.2 \mathrm{a}$ & $33.3 \mathrm{a}$ & $23.2 \mathrm{a}$ \\
\hline Drenches & $45.0 \mathrm{~b}$ & $22.4 \mathrm{~b}$ & $58.1 \mathrm{~b}$ & $26.1 \mathrm{~b}$ & $31.0 \mathrm{~b}$ & $20.3 b$ \\
\hline Foliar sprays & $46.4 \mathrm{ab}$ & $23.2 \mathrm{~b}$ & $57.0 \mathrm{~b}$ & $25.6 \mathrm{~b}$ & $29.2 \mathrm{c}$ & $19.8 \mathrm{~b}$ \\
\hline \multicolumn{7}{|l|}{ Two-way } \\
\hline \multicolumn{7}{|l|}{ ANOVA } \\
\hline $\mathrm{C}$ & $* *$ & $* * *$ & $* * *$ & $* * *$ & $* * *$ & $* *$ \\
\hline M & $*$ & $* * *$ & $* *$ & $* *$ & $* * *$ & $* * *$ \\
\hline $\mathrm{C} \times \mathrm{M}$ & ns & $* *$ & * & ns & $* * *$ & ns \\
\hline
\end{tabular}


Table 2. Main effects of silver nanoparticle (AgNP) concentration and application method on flowering of lily cv. Mona Lisa. Values followed by differing letters in each column are significantly different at $p \leq 0.05$ (ANOVA and Tukey's test). ***: Significant at $p \leq 0.05,0.01$ or 0.001 , respectively. Non-significant: ns.

\begin{tabular}{cccccc}
\hline $\begin{array}{c}\text { AgNP } \\
\text { Treatment }\end{array}$ & $\begin{array}{c}\text { Days to } \\
\text { Anthesis }\end{array}$ & $\begin{array}{c}\text { No. of Flowers } \\
\text { Per Plant }\end{array}$ & $\begin{array}{c}\text { Tepal Length } \\
\text { (cm) }\end{array}$ & $\begin{array}{c}\text { Tepal Width } \\
\text { (cm) }\end{array}$ & $\begin{array}{c}\text { Flower Longevity } \\
\text { (Days) }\end{array}$ \\
\hline $\begin{array}{c}\text { Concentration } \\
(\mathrm{C})\end{array}$ & & & & & \\
$0 \mathrm{ppm}$ & $109 \mathrm{~b}$ & $2.7 \mathrm{~b}$ & $11.7 \mathrm{a}$ & $5.76 \mathrm{a}$ & $9.50 \mathrm{~b}$ \\
$25 \mathrm{ppm}$ & $107 \mathrm{a}$ & $3.6 \mathrm{ab}$ & $11.9 \mathrm{a}$ & $5.76 \mathrm{a}$ & $10.3 \mathrm{ab}$ \\
$50 \mathrm{ppm}$ & $106 \mathrm{a}$ & $4.0 \mathrm{a}$ & $12.0 \mathrm{a}$ & $5.89 \mathrm{a}$ & $11.4 \mathrm{a}$ \\
$100 \mathrm{ppm}$ & $106 \mathrm{a}$ & $4.0 \mathrm{a}$ & $12.0 \mathrm{a}$ & $5.93 \mathrm{a}$ & $11.0 \mathrm{ab}$ \\
$150 \mathrm{ppm}$ & $107 \mathrm{a}$ & $3.4 \mathrm{ab}$ & $12.0 \mathrm{a}$ & $5.80 \mathrm{a}$ & $10.6 \mathrm{ab}$ \\
Method (M) & & & & & \\
Bulb soaks & $106 \mathrm{a}$ & $4.0 \mathrm{a}$ & $11.9 \mathrm{a}$ & $5.91 \mathrm{a}$ & $10.3 \mathrm{a}$ \\
Drenches & $107 \mathrm{~b}$ & $3.1 \mathrm{~b}$ & $11.8 \mathrm{a}$ & $5.74 \mathrm{a}$ & $11.0 \mathrm{a}$ \\
Foliar sprays & $107 \mathrm{~b}$ & $3.4 \mathrm{~b}$ & $12.0 \mathrm{a}$ & $5.84 \mathrm{a}$ & $10.4 \mathrm{a}$ \\
Two-way & & & & & \\
ANOVA & $* *$ & $*$ & $\mathrm{~ns}$ & $\mathrm{~ns}$ & \\
C & $*$ & $\mathrm{~ns}$ & $\mathrm{~ns}$ & $\mathrm{~ns}$ & $\mathrm{~ns}$ \\
M & $\mathrm{ns}$ & & $\mathrm{ns}$ & $\mathrm{ns}$ & $\mathrm{ns}$ \\
C $\times$ M & & & & & \\
\hline
\end{tabular}

As for the AgNP application methods, cv. Mona Lisa lilies grown from the bulbs soaked in nanoparticle solutions produced significantly more leaves and flowers and had higher greenness indices and fresh weight of leaves and bulbs than plants watered or sprayed with AgNPs. In addition, soaking the bulbs in AgNP solution accelerated flowering and increased the number of flowers without affecting flower longevity (Tables 1 and 2).

For the number of leaves, greenness index, and bulb fresh weight, we found a significant interaction between AgNP concentration and its application method (Table 3).

Table 3. The interaction effects of application method and silver nanoparticle (AgNP) concentration on the number of leaves, greenness index, and bulb fresh weight of lily cv. Mona Lisa. Values followed by differing letters in each column are significantly different at $p \leq 0.05$ (ANOVA and Tukey's test).

\begin{tabular}{|c|c|c|c|c|}
\hline \multicolumn{2}{|c|}{ AgNP Treatment } & \multirow{2}{*}{$\begin{array}{c}\text { No. of Leaves Per } \\
\text { Plant }\end{array}$} & \multirow{2}{*}{$\begin{array}{c}\text { Greenness Index } \\
\text { (SPAD) }\end{array}$} & \multirow{2}{*}{$\begin{array}{c}\text { Bulb Fresh Weight } \\
\text { (g/Plant) }\end{array}$} \\
\hline Method & Concentration & & & \\
\hline \multirow{5}{*}{ Bulb soaks } & $0 \mathrm{ppm}$ & $21.3 c$ & $52.3 \mathrm{~d}$ & $21.4 \mathrm{~g}$ \\
\hline & $25 \mathrm{ppm}$ & $29.2 \mathrm{ab}$ & $59.2 \mathrm{abcd}$ & $40.2 \mathrm{a}$ \\
\hline & 50 ppm & $24.8 \mathrm{bc}$ & $68.3 \mathrm{a}$ & $39.3 \mathrm{ab}$ \\
\hline & $100 \mathrm{ppm}$ & $24.5 \mathrm{bc}$ & $66.1 \mathrm{ab}$ & $33.4 \mathrm{~cd}$ \\
\hline & $150 \mathrm{ppm}$ & $34.5 \mathrm{a}$ & $60.1 \mathrm{abcd}$ & 32.2 de \\
\hline \multirow{5}{*}{ Drenches } & $0 \mathrm{ppm}$ & $21.3 \mathrm{c}$ & $52.3 \mathrm{~d}$ & $21.4 \mathrm{~g}$ \\
\hline & $25 \mathrm{ppm}$ & $24.0 \mathrm{bc}$ & $56.1 \mathrm{~cd}$ & $26.4 \mathrm{fg}$ \\
\hline & $50 \mathrm{ppm}$ & $22.0 \mathrm{c}$ & $56.7 \mathrm{~cd}$ & $40.9 \mathrm{a}$ \\
\hline & $100 \mathrm{ppm}$ & $23.0 \mathrm{bc}$ & $62.1 \mathrm{abc}$ & $33.8 \mathrm{bcd}$ \\
\hline & $150 \mathrm{ppm}$ & $21.8 \mathrm{c}$ & $63.3 \mathrm{abc}$ & 32.6 cde \\
\hline \multirow{5}{*}{ Foliar sprays } & $0 \mathrm{ppm}$ & $21.3 c$ & $52.3 \mathrm{~d}$ & $21.4 \mathrm{~g}$ \\
\hline & 25 ppm & $23.7 \mathrm{bc}$ & $55.1 \mathrm{~cd}$ & $27.4 \mathrm{ef}$ \\
\hline & 50 ppm & $23.1 \mathrm{bc}$ & 59.5 abcd & $31.0 \mathrm{def}$ \\
\hline & $100 \mathrm{ppm}$ & $23.0 \mathrm{bc}$ & $57.6 \mathrm{bcd}$ & $37.9 \mathrm{abc}$ \\
\hline & $150 \mathrm{ppm}$ & $25.1 \mathrm{bc}$ & $60.3 \mathrm{abcd}$ & $28.4 \mathrm{def}$ \\
\hline
\end{tabular}

In the second year of the study, we focused on cv. Little John and chose the most effective method of AgNP application, i.e., bulb soaking. The data we obtained for this cultivar confirmed the stimulatory effects of AgNPs on lily growth and flowering (Figure 1, Table 4). Plants treated with all 
investigated concentrations of AgNPs reached significantly greater fresh weight of leaves (28.6-47.9\%) and bulbs (40.6-56.5\%), and produced more flowers (4.5-14.9\%) with longer tepals (9.7-13.7\%) than control ones. Moreover, AgNP presence accelerated flowering by two to four days, except for the concentration of $150 \mathrm{ppm}$. The most beneficial AgNP concentration was $100 \mathrm{ppm}$, at which the plants were the highest $(56.5 \mathrm{~cm})$, produced the greatest number of leaves $(65.7)$, had the highest greenness index $(59.4 \mathrm{SPAD})$, the longest $(14.1 \mathrm{~cm})$ and the widest $(7.03 \mathrm{~cm})$ tepals, and flowered for the longest time (18.2 days).

Table 4. Effects of silver nanoparticle (AgNP) pre-planting bulb soaks on growth and flowering of lily cv. Little John. Values for each parameter followed by differing letters are significantly different at $p \leq 0.05$ (ANOVA and Tukey's test). ${ }^{*}, * * * * *$ Significant at $p \leq 0.05,0.01$ or 0.001 , respectively.

\begin{tabular}{ccccccc}
\hline \multirow{2}{*}{ Parameters } & \multicolumn{4}{c}{ AgNP Concentration } & \multicolumn{2}{c}{$\begin{array}{c}\text { One-Way } \\
\text { ANOVA }\end{array}$} \\
\cline { 2 - 5 } & $\mathbf{0}$ & $\mathbf{2 5} \mathbf{~ p p m}$ & $\mathbf{5 0} \mathbf{~ p m}$ & $\mathbf{1 0 0} \mathbf{~ p m}$ & $\mathbf{1 5 0} \mathbf{~ p p m}$ & \\
\hline Plant height (cm) & $48.8 \mathrm{a}$ & $53.3 \mathrm{~b}$ & $54.7 \mathrm{ab}$ & $56.5 \mathrm{a}$ & $53.5 \mathrm{~b}$ & $* *$ \\
No. of leaves per plant & $58.3 \mathrm{~b}$ & $59.3 \mathrm{ab}$ & $63.0 \mathrm{ab}$ & $65.7 \mathrm{a}$ & $61.7 \mathrm{ab}$ & $*$ \\
Greenness index (SPAD) & $48.5 \mathrm{c}$ & $54.6 \mathrm{~b}$ & $56.6 \mathrm{ab}$ & $59.4 \mathrm{a}$ & $55.4 \mathrm{ab}$ & $* *$ \\
Leaves fresh weight (g) & $35.3 \mathrm{~b}$ & $45.4 \mathrm{a}$ & $50.6 \mathrm{a}$ & $52.2 \mathrm{a}$ & $50.0 \mathrm{a}$ & $*$ \\
Bulb fresh weight (g) & $52.4 \mathrm{~b}$ & $73.7 \mathrm{a}$ & $79.8 \mathrm{a}$ & $82.0 \mathrm{a}$ & $74.2 \mathrm{a}$ & $* * *$ \\
No. of scales per bulb & $31.7 \mathrm{c}$ & $38.3 \mathrm{~b}$ & $39.7 \mathrm{~b}$ & $43.0 \mathrm{a}$ & $43.3 \mathrm{a}$ & $*$ \\
Days to anthesis & $113 \mathrm{~b}$ & $110 \mathrm{a}$ & $110 \mathrm{a}$ & $109 \mathrm{a}$ & $111 \mathrm{ab}$ & $*$ \\
No. of flowers per plant & $6.7 \mathrm{~b}$ & $7.5 \mathrm{a}$ & $7.7 \mathrm{a}$ & $7.7 \mathrm{a}$ & $7.0 \mathrm{a}$ & $*$ \\
Tepal length (cm) & $12.4 \mathrm{~b}$ & $13.6 \mathrm{a}$ & $13.7 \mathrm{a}$ & $14.1 \mathrm{a}$ & $13.6 \mathrm{a}$ & $*$ \\
Tepal width (cm) & $6.19 \mathrm{~b}$ & $6.80 \mathrm{ab}$ & $6.84 \mathrm{ab}$ & $7.03 \mathrm{a}$ & $6.93 \mathrm{ab}$ & $*$ \\
Flower longevity (days) & $14.2 \mathrm{~b}$ & $15.3 \mathrm{ab}$ & $16.5 \mathrm{ab}$ & $18.2 \mathrm{a}$ & $15.5 \mathrm{ab}$ & $*$ \\
\hline
\end{tabular}

\subsection{Effect of AgNPs on Photosynthetic Pigments and Macronutrient Concentration}

Our study showed a significant effect of AgNPs on the leaf content of photosynthetic pigments (Figure 2). Leaves of the lily cv. Little John treated with $100 \mathrm{ppm}$ of AgNPs accumulated the greatest amounts of chlorophyll $a$, chlorophyll $b$, chlorophyll $a+b$, and carotenoids. For this treatment, the levels of chlorophyll $a$, chlorophyll $b$, chlorophyll $a+b$, and carotenoids were higher by 31.2, 23.1, 28.6 , and $26.3 \%$ than in control, respectively. Leaf content of nitrogen, potassium, calcium, and sulfur also depended on AgNP concentration (Figure 3). In comparison with the control plants, AgNPs at 50 ppm enhanced nitrogen and potassium content by 9.2 and $16.1 \%$, respectively. Plants treated with $100 \mathrm{ppm}$ AgNPs also showed significantly higher levels of potassium (by $14.9 \%$ ), as well as calcium (by $14.4 \%$ ) and sulfur (by $25.5 \%$ ). The contents of phosphorus and magnesium were unaffected by AgNP treatments (Figure 3). 

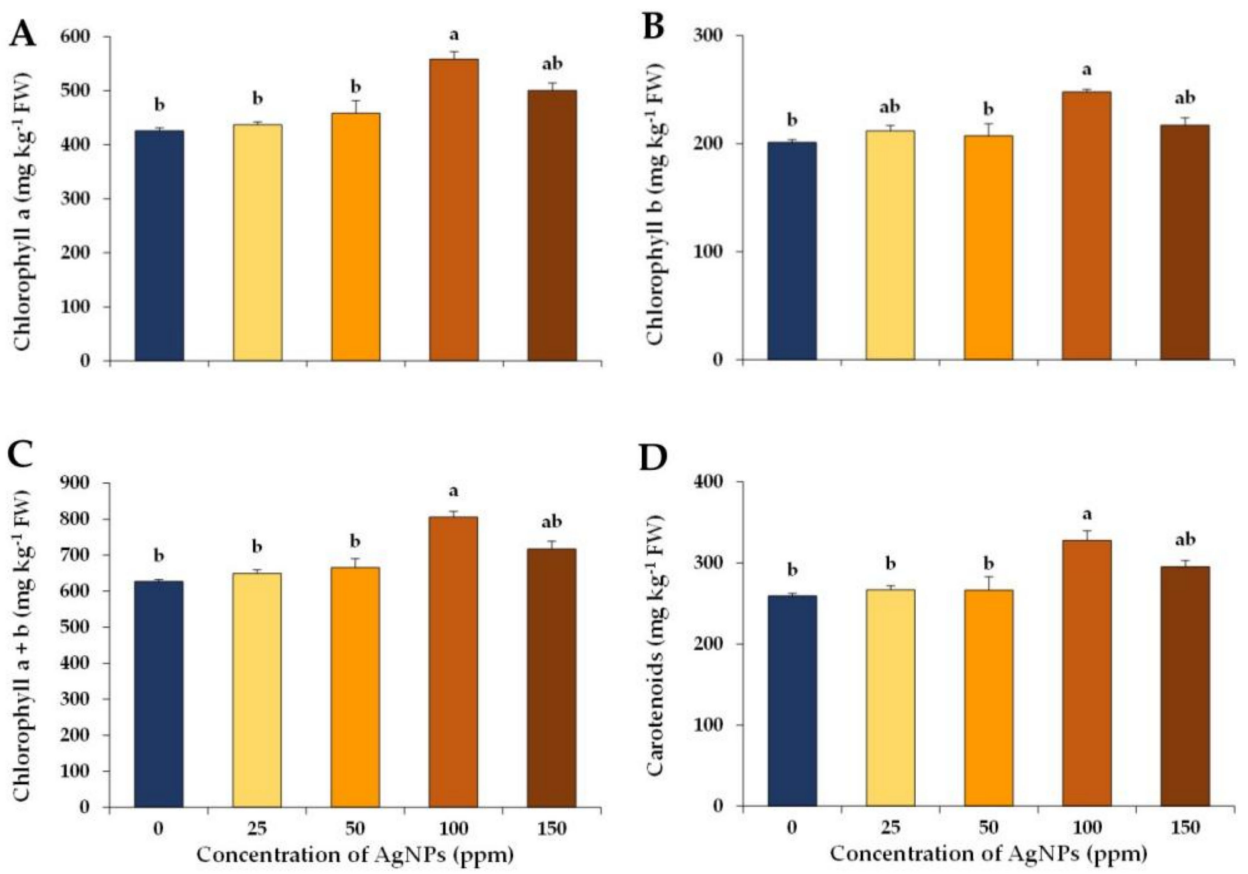

Figure 2. Effects of silver nanoparticle (AgNP) pre-planting bulb soaks on chlorophyll a (A), chlorophyll $\mathrm{b}(\mathbf{B})$, chlorophyll $\mathrm{a}+\mathrm{b}(\mathbf{C})$, and carotenoid (D) content of lily cv. Little John. Vertical bars indicate the standard error (SE) of the mean. A different lower-case letter above each bar in each panel indicates a significant difference between treatment at $p \leq 0.05$ (ANOVA and LSD test). FW: fresh weight. 

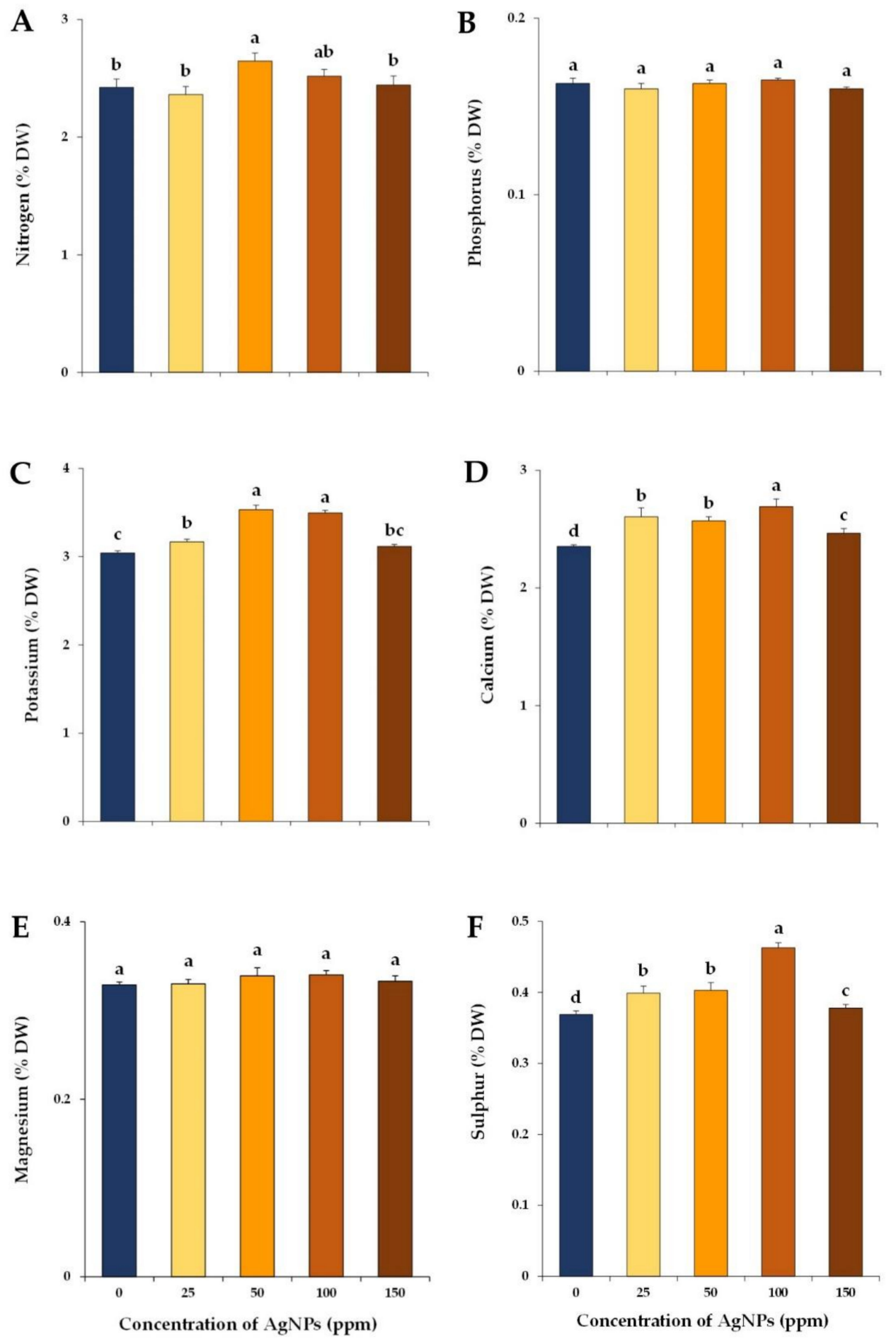

Figure 3. Effects of silver nanoparticles (AgNPs) preplant bulb soaks on leaf nitrogen (A); phosphorus (B); potassium (C); calcium (D); magnesium (E) and sulphur (F) content of lily cv. Little John. Vertical bars indicate the standard error (SE) of the mean. A different lower-case letter above each bar in each panel indicates a significant difference between treatment at $p \leq 0.05$ (ANOVA and LSD test). DW: dry weight.

\subsection{FTIR Analysis}

The study analyzed five regions in the FTIR spectra: (1) from 3600 to $3200 \mathrm{~cm}^{-1}$, (2) from 3200 to $2800 \mathrm{~cm}^{-1}$, (3) from 1800 to $1500 \mathrm{~cm}^{-1}$, (4) from 1400 to $1200 \mathrm{~cm}^{-1}$, and (5) from 1200 to $900 \mathrm{~cm}^{-1}$ 
(Figure 4). In the case of the $3285.90 \mathrm{~cm}^{-1}$ peak, its consistency with absorption was noted, stimulated by O-H single bonds. By contrast, spectrum peaks at 2917.58, 2850.42, and $1411.25 \mathrm{~cm}^{-1}$ were consistently observed for a peak with $\mathrm{CH}_{3}-\mathrm{CH}_{2}$ induced absorption. The $1590.73 \mathrm{~cm}^{-1}$ and $1587.03 \mathrm{~cm}^{-1}$ peaks corresponded to lipids and pectin. Spectrum peaks at 1026.40, 1026.85, and $1098.49 \mathrm{~cm}^{-1}$ were consistently observed for a peak with $\mathrm{O}-\mathrm{H}$ - and $\mathrm{C}-\mathrm{O}$-induced absorption, which mainly occurs in carbohydrates [33]. The FTIR analysis did not show any influence of AgNPs on the location and relative intensity of the oscillation bands.

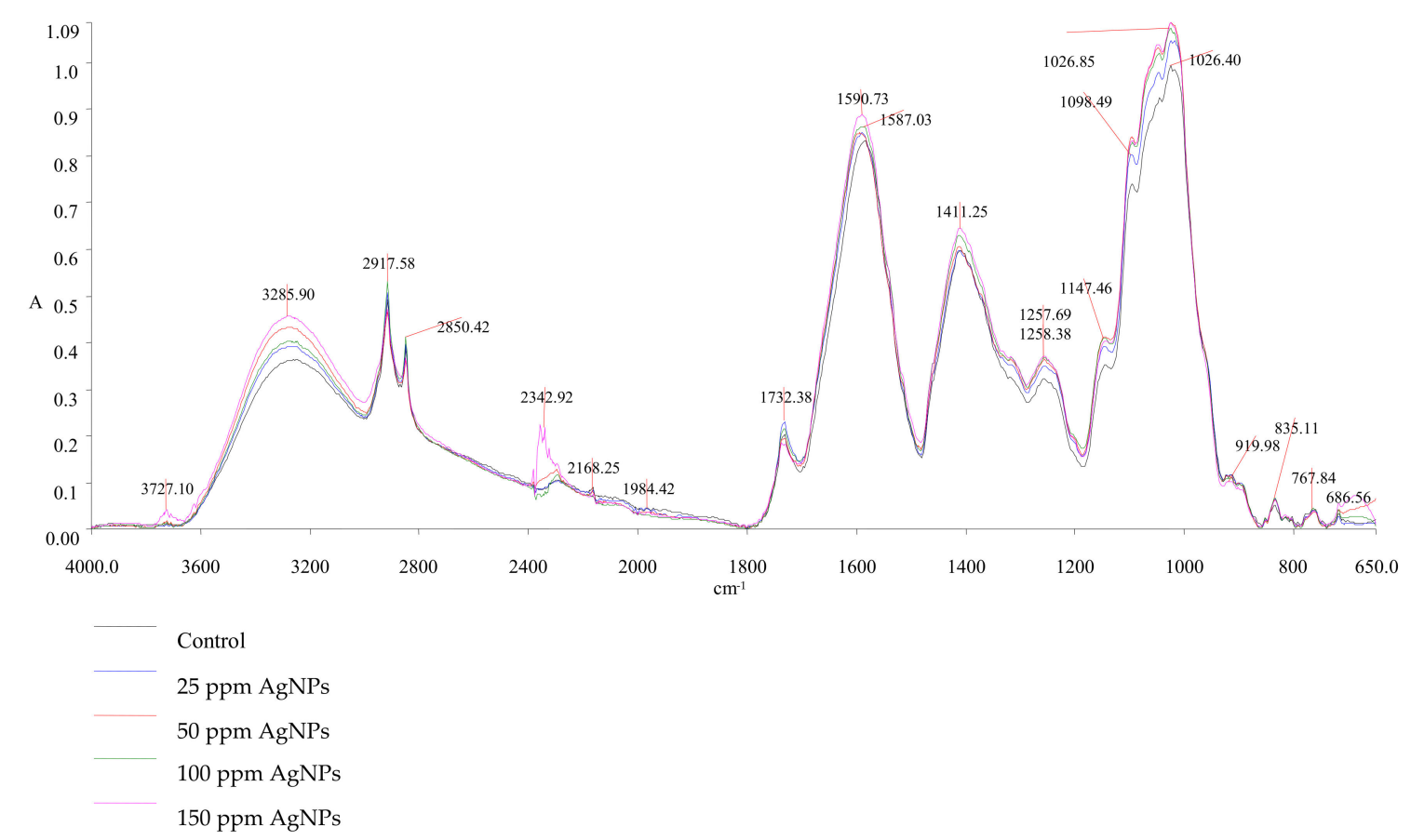

Figure 4. Fourier-transform infrared (FTIR) spectra (region $4000-650 \mathrm{~cm}^{-1}$ ) from leaf samples of lily cv. Little John after the application of silver nanoparticle (AgNP) pre-planting bulb soaks.

\section{Discussion}

The study demonstrated positive effects of AgNPs on lily production, as manifested in enhanced growth and more abundant flowering. Plants treated with AgNPs responded with accelerated anthesis, higher greenness index, greater number of flowers, and prolonged flowering, which translated into a greater decorative and commercial value than that of non-treated plants. Additionally, AgNPs considerably increased bulb weight and the number of scales, reflecting improved reproduction potential of the species. Leaves of lilies treated with AgNPs showed no signs of necrosis, chlorosis, leaf and bud drying, or other symptoms of decreased plant quality (Figure 1). Lily cv. Mona Lisa developed the most preferable morphological features when treated with $50 \mathrm{ppm}$ AgNPs, while for $\mathrm{cv}$. Little John, the optimal concentration of nanoparticles was $100 \mathrm{ppm}$. We have previously reported similar results confirming the beneficial effects of $100 \mathrm{ppm}$ AgNPs, applied by pre-planting soak, on the yield of cut flowers and daughter bulbs of Tulipa gesneriana cv. Pink Impression [30]. Dipping cuttings in 50 and $100 \mathrm{ppm}$ AgNP solutions in lily propagation via bulb scales increased the weight of bulblets and their adventitious roots [34]. In in vitro cultures of lily, supplementation of media with AgNPs stimulated morphogenesis and elimination of bacterial contaminations [35]. Information on using AgNPs in the cultivation and propagation of ornamental bulbous plants is scarce, and while data on AgNP treatment in other plant groups are more abundant, they are often contradictory. Phytostimulatory effects of biosynthesized AgNPs on seedling elongation and their biomass growth have been reported in Oryza sativa [17] and Trigonella foenum-graceum [16]. Treatment 
of Chrysanthemum morifolium with $7.5 \mathrm{ppm}$ AgNPs applied to tissue cultures significantly improved plant height, length and width of leaves, and plant fresh and dry weight [36]. In Swertia chirata, supplementation of the cultivation media with AgNPs of $20 \mathrm{~nm}$ in diameter favorably influenced shoot morphogenesis [7]. Contrary to that, exposing Capsicum annum to soil-drench-applied AgNPs inhibited plant growth and reduced biomass accumulation of the above-ground parts [20]. Seedlings of Lupinus termis treated with high concentrations of AgNPs (300-500 ppm) responded with a reduction in shoot and root elongation and decreased biomass accumulation. However, AgNPs at 100 ppm stimulated shoot and root growth [37]. Similarly, positive effects of low-concentrated solution of AgNP on seedling development were reported in Pisum sativum [38]. Inconsistent plant responses to AgNPs may be due to the fact that nanoparticle actions depend on plant genotype [39,40], AgNP concentration [41,42], and application method [43], as confirmed in our study. Bulb soaking in various concentrations of nanoparticles turned out to be more effective than drenching or spraying. It could be assumed that bulbs treated with AgNPs prior to planting were more resistant to soil pathogen infections, and thus their growth and development was more vigorous from the beginning of the cultivation. AgNPs are known for their high antimicrobial activity and effective plant protection against various diseases [1,4,12]. A suggested beneficial effect on lily disease of AgNPs still needs to be further studied. Other factors, such as nanoparticle size, shape [44], or synthesis method [41,45] also make it difficult to compare the results of different studies and to explain the mechanisms of AgNP action. Different plant responses to different AgNP doses may be the effect of hormesis, i.e., a stimulatory influence of low doses and inhibitory influence of high doses of the same agent [46]. According to Juárez-Maldonado et al. [47], the surface charges of nanoparticles interact with the surface charges of plant cells, inducing plant responses from biostimulation to toxicity. These authors assume a two-stage biostimulation process. The initial stage of physicochemical character involves the interaction of surface charges, while the later stage consists of a series of biochemical stimuli that promote nanoparticle penetration into the cells or cause changes in the membranes or integral proteins [47].

Leaf contents of assimilation pigments and macronutrients serve as important biomarkers of plant physiological condition. Increased synthesis of chlorophyll and more effective uptake of minerals are known to considerably improve plant growth and enhance biomass production. In our study, pre-planting bulb soaks of AgNPs at 100 ppm increased leaf content of chlorophyll a, chlorophyll b, and carotenoids, as well as the levels of potassium, calcium, and sulfur. We also saw enhanced accumulation of potassium, accompanied by greater content of nitrogen in plants treated with AgNPs at $50 \mathrm{ppm}$. Stimulation of chlorophyll synthesis following AgNP foliar application has been demonstrated previously in the leaves of Triticum aestivum [18]. AgNPs are assumed to exert a pleiotropic effect on plants by affecting their physiological and biochemical processes and gene expression profiles. Supplementing soil substrate with AgNPs resulted in considerable increase in leaf chlorophyll content, nitrogen and phosphorus uptake, accumulation of crude protein, and enhanced expression of mRNA for nitrate reductase and ferredoxin in a culture of Phaseolus vulgaris [41]. Syu et al. [44] demonstrated that phytostimulatory activity of medium-applied AgNPs on the growth of Arabidopsis correlated with accumulation of proteins associated with the cell cycle and carbohydrate metabolism, and changes in the expression of the genes involved in multiple cellular processes, such as cell proliferation, photosynthesis, and signaling pathways of such hormones as auxins, abscisic acid, and ethylene. Gupta et al. [17] reported AgNP-stimulated growth improvement in Oryza sativa seedlings accompanied by elevated levels of catalase, ascorbate peroxidase, and glutathione reductase, and decreased amounts of lipid peroxidation and hydrogen peroxide content. By enhancing the activity of antioxidant enzymes, the nanoparticles probably help to reduce oxidative stress and may reinforce plant responses to other types of stresses, such as salinity or high temperature [48,49].

Macromolecules are the main building blocks of plant bodies and their endogenously determined composition may be modified by external factors, including nanoparticles and nanocompounds [50]. To obtain comprehensive data on the composition of plant macromolecules, we carried out vibrational spectroscopy FTIR that enabled the identification of individual functional groups and detection of 
changes in various chemical bonds. We found that AgNP treatment did not alter the macromolecular composition of lily leaves. However, our findings were inconsistent with a study by Zuverza-Mena et al. [33], where FTIR analysis detected changes in the bands corresponding to lipids (3000-2800 $\mathrm{cm}^{-1}$ ), proteins (1550-1530 $\mathrm{cm}^{-1}$ ), and structural components such as lignin, pectin, and cellulose in Raphanus sativus seedlings grown in AgNP suspensions. In Lycopersicum esculentum, grown in sewage sludge amendment soil containing $\mathrm{TiO}_{2}$ nanoparticles, FTIR analysis revealed a decrease in tannins and lignins and an increase in carbohydrates in leaves, but no changes in fruits [51]. The effect of AgNPs on the physiological responses, mineral status, and macromolecule conformation in plants is still an open question.

\section{Conclusions}

Our study showed that AgNPs used in the form of bulb-soaking solutions stimulated growth and flowering of two cultivars of Oriental lily. AgNP application resulted in enhanced leaf and bulb biomass, leaf greenness index, and flower abundance. Additionally, the plants treated with AgNPs began their anthesis earlier and featured prolonged flower longevity, meaning their decorative period was longer, which is a top priority in floriculture. The effects of AgNPs on plant growth and the content of assimilation pigments and some macronutrients depended on nanoparticle concentration. In most cases, the best effects were achieved for 50 and $100 \mathrm{ppm}$. FTIR spectroscopy showed no quantitative or qualitative changes in macromolecules and individual functional groups in response to AgNP treatment. The unique properties of AgNPs may be highly beneficial in the cultivation of ornamental bulb plants, but, as their mechanisms of action are not fully understood, further detailed mycological, biochemical, and molecular studies on the impact of nanosilver on plant health and stress are necessary.

Author Contributions: Conceived and designed the experiments, A.B., P.S. and A.Z.; Collected and analyzed the data, A.B., M.M. and R.P., Wrote the paper: P.S., A.B. and M.M.

Funding: The study was supported by the Polish Ministry of Science and Higher Education (Project UPB 517-07-014-5365/17 ZUT).

Acknowledgments: The authors would like to thank Róża Stuart for her help in the lab.

Conflicts of Interest: The authors declare no conflict of interest.

\section{References}

1. Rai, P.K.; Kumar, V.; Lee, S.; Raza, N.; Kim, K.H.; Ok, Y.S.; Tsang, D.C. Nanoparticle-plant interaction: Implications in energy, environment, and agriculture. Environ. Int. 2018, 119, 1-19. [CrossRef] [PubMed]

2. Khan, M.N.; Mobin, M.; Abbas, Z.K.; AlMutairi, K.A.; Siddiqui, Z.H. Role of nanomaterials in plants under challenging environments. Plant Physiol. Biochem. 2017, 110, 194-209. [CrossRef] [PubMed]

3. Elmer, W.H.; White, J.C. The use of metallic oxide nanoparticles to enhance growth of tomatoes and eggplants in disease infested soil or soilless medium. Environ. Sci. Nano. 2016, 3, 1072-1079. [CrossRef]

4. Worrall, E.; Hamid, A.; Mody, K.; Mitter, N.; Pappu, H. Nanotechnology for plant disease management. Agronomy 2018, 8, 285. [CrossRef]

5. Maruyama, C.R.; Guilger, M.; Pascoli, M.; Bileshy-José, N.; Abhilash, P.C.; Fraceto, L.F.; De Lima, R. Nanoparticles based on chitosan as carriers for the combined herbicides imazapic and imazapyr. Sci. Rep. 2016, 6, 19768. [CrossRef]

6. He, Y.; Qian, L.; Liu, X.; Hu, R.; Huang, M.; Liu, Y.; Chen, G.; Losic, D.; Zhu, H. Graphene oxide as an antimicrobial agent can extend the vase life of cut flowers. Nano Res. 2018, 11, 6010-6022. [CrossRef]

7. Saha, N.; Gupta, S.D. Promotion of shoot regeneration of Swertia chirata by biosynthesized silver nanoparticles and their involvement in ethylene interceptions and activation of antioxidant activity. Plant Cell Tissue Organ Culture 2018, 134, 289-300. [CrossRef]

8. Thangavelu, R.M.; Gunasekaran, D.; Jesse, M.I.; Su, M.R.; Sundarajan, D.; Krishnan, K. Nanobiotechnology approach using plant rooting hormone synthesized silver nanoparticle as "nanobullets" for the dynamic applications in horticulture-An in vitro and ex vitro study. Arab. J. Chem. 2016, 11, 48-61. [CrossRef] 
9. Hernández-Hernández, H.; González-Morales, S.; Benavides-Mendoza, A.; Ortega-Ortiz, H.; Cadenas-Pliego, G.; Juárez-Maldonado, A. Effects of chitosan-PVA and Cu nanoparticles on the growth and antioxidant capacity of tomato under saline stress. Molecules 2018, 23, 178. [CrossRef]

10. Avestan, S.; Ghasemnezhad, M.; Esfahani, M.; Byrt, C.S. Application of nano-silicon dioxide improves salt stress tolerance in strawberry plants. Agronomy 2019, 9, 246. [CrossRef]

11. Feregrino-Perez, A.A.; Magaña-López, E.; Guzmán, C.; Esquivel, K. A general overview of the benefits and possible negative effects of the nanotechnology in horticulture. Sci. Hortic. 2018, 238, 126-137. [CrossRef]

12. Haider, A.; Kang, I.K. Preparation of silver nanoparticles and their industrial and biomedical applications: A comprehensive review. Adv. Mater. Sci. Eng. 2015. [CrossRef]

13. Zuverza-Mena, N.; Martínez-Fernández, D.; Du, W.; Hernandez-Viezcas, J.A.; Bonilla-Bird, N.; López-Moreno, M.L.; Komarek, M.; Peralta-Videa, J.R.; Gardea-Torresdey, J.L. Exposure of engineered nanomaterials to plants: Insights into the physiological and biochemical responses-A review. Plant Physiol. Biochem. 2017, 110, 236-264. [CrossRef] [PubMed]

14. Mehmood, A. Brief overview of the application of silver nanoparticles to improve growth of crop plants. IET Nanobiotechnol. 2018, 12, 701-705. [CrossRef] [PubMed]

15. Parveen, A.; Rao, S. Effect of nanosilver on seed germination and seedling growth in Pennisetum glaucum. J. Clust. Sci. 2015, 26, 693-701. [CrossRef]

16. Jasim, B.; Thomas, R.; Mathew, J.; Radhakrishnan, E.K. Plant growth and diosgenin enhancement effect of silver nanoparticles in Fenugreek (Trigonella foenum-graecum L.). Saudi Pharm. J. 2017, 25, 443-447. [CrossRef]

17. Gupta, S.D.; Agarwal, A.; Pradhan, S. Phytostimulatory effect of silver nanoparticles (AgNPs) on rice seedling growth: An insight from antioxidative enzyme activities and gene expression patterns. Ecotoxicol. Environ. Saf. 2018, 161, 624-633. [CrossRef]

18. Latif, H.H.; Ghareib, M.; Tahon, M.A. Phytosynthesis of silver nanoparticles using leaf extracts from Ocimum basilicum and Mangifira indica and their effect on some biochemical attributes of Triticum aestivum. Gesunde Pflanz. 2017, 69, 39-46. [CrossRef]

19. Geisler-Lee, J.; Brooks, M.; Gerfen, J.; Wang, Q.; Fotis, C.; Sparer, A.; Ma, X.; Berg, R.H.; Geisler, M. Reproductive toxicity and life history study of silver nanoparticle effect, uptake and transport in Arabidopsis thaliana. Nanomaterials 2014, 4, 301-318. [CrossRef]

20. Vinković, T.; Novák, O.; Strnad, M.; Goessler, W.; Jurašin, D.D.; Parađiković, N.; Vrček, I.V. Cytokinin response in pepper plants (Capsicum annuum L.) exposed to silver nanoparticles. Environ. Res. 2017, 156, 10-18. [CrossRef]

21. Ke, M.; Qu, Q.; Peijnenburg, W.J.G.M.; Li, X.; Zhang, M.; Zhang, Z.; Lu, T.; Pan, X.; Qian, H. Phytotoxic effects of silver nanoparticles and silver ions to Arabidopsis thaliana as revealed by analysis of molecular responses and of metabolic pathways. Sci. Total Environ. 2018, 644, 1070-1079. [CrossRef] [PubMed]

22. Allegra, V.; Zarba, A.S.; Muratore, F. The ornamental potted plants: Circular economy in agriculture. Qual. Access Success 2019, 20,7-12.

23. Okubo, H.; Sochacki, D. Botanical and horticultural aspects of major ornamental geophytes. In Ornamental Geophytes: From Basic Science to Sustainable Production; Kamenetsky, R., Okubo, H., Eds.; CRC Press Taylor \& Francis Group: Boca Raton, FL, USA, 2012; pp. 79-116. [CrossRef]

24. Beers, C.M.; Barba-Gonzalez, R.; van Silfhout, A.A.; Ramanna, M.S.; van Tuyl, J.M. Mitotic and meiotic polyploidization in lily hybrids for transferring Botrytis resistance. Acta Hortic. 2004, 673, 449-452. [CrossRef]

25. Conijn, C.G.M. Developments in the control of lily diseases. Acta Hortic. 2014, 1027, 213-229. [CrossRef]

26. Salachna, P.; Grzeszczuk, M.; Soból, M. Effects of chitooligosaccharide coating combined with selected ionic polymers on the stimulation of Ornithogalum saundersiae growth. Molecules 2017, 22, 1903. [CrossRef]

27. Cristiano, G.; Pallozzi, E.; Conversa, G.; Tufarelli, V.; De Lucia, B. Effects of an animal-derived biostimulant on the growth and physiological parameters of potted snapdragon (Antirrhinum majus L.). Front. Plant Sci. 2018, 9, 861. [CrossRef] [PubMed]

28. De Lucia, B.; Vecchietti, L. Type of bio-stimulant and application method effects on stem quality and root system growth in LA Lily. Eur. J. Hortic. Sci. 2012, 77, 10.

29. Shafiee-Masouleh, S.S.; Hatamzadeh, A.; Samizadeh, H.; Rad-Moghadam, K. Enlarging bulblet by magnetic and chelating structures of nano-chitosan as supplementary fertilizer in Lilium. Hortic. Environ. Biot. 2014, 55, 437-444. [CrossRef] 
30. Byczyńska, A.; Zawadzińska, A.; Salachna, P. Silver nanoparticles preplant bulb soaking affects tulip production. Acta Agric. Scand. B Soil Plant 2019, 69, 250-256. [CrossRef]

31. Arnon, D.I.; Allen, M.B.; Whatley, F.R. Photosynthesis by isolated chloroplasts IV. General concept and comparison of three photochemical reactions. Biochim. Biophys. Acta Gen. Subj. 1956, 20, 449-461. [CrossRef]

32. Hager, A.; Meyer-Bertenrath, T. Die isolierung und quantitative bestimmung der carotinoide und chlorophylle von blättern, algen und isolierten chloroplasten mit hilfe dünnschichtchromatographischer methoden. Planta 1966, 69, 198-217. [CrossRef] [PubMed]

33. Zuverza-Mena, N.; Armendariz, R.; Peralta-Videa, J.R.; Gardea-Torresdey, J.L. Effects of silver nanoparticles on radish sprouts: Root growth reduction and modifications in the nutritional value. Front. Plant Sci. 2016, 7, 90. [CrossRef] [PubMed]

34. Byczyńska, A.; Zawadzińska, A.; Salachna, P. Effects of nano-silver on bulblet production from bulb scales of lilium. Propag. Ornam. Plants 2018, 18, 104-106.

35. Gioi, D.H.; Huong, B.T.T.; Luu, N.T.B. The effects of different concentrations of nano silver on elimination of bacterial contaminations and stimulation of morphogenesis of Sorbonne lily in vitro culture. Acta Hortic. 2019, 1237, 227-234. [CrossRef]

36. Tung, H.T.; Nam, N.B.; Huy, N.P.; Luan, V.Q.; Hien, V.T.; Phuong, T.T.B.; Nhut, D.T. A system for large scale production of chrysanthemum using microponics with the supplement of silver nanoparticles under light-emitting diodes. Sci. Hortic. 2018, 232, 153-161. [CrossRef]

37. Al-Huqail, A.A.; Hatata, M.M.; Al-Huqail, A.A.; Ibrahim, M.M. Preparation, characterization of silver phyto nanoparticles and their impact on growth potential of Lupinus termis L. seedlings. Saudi J. Biol. Sci. 2018, 25, 313-319. [CrossRef]

38. Barabanov, P.V.; Gerasimov, A.V.; Blinov, A.V.; Kravtsov, A.A.; Kravtsov, V.A. Influence of nanosilver on the efficiency of Pisum sativum crops germination. Ecotoxicol. Environ. Saf. 2018, 147, 715-719. [CrossRef]

39. Yin, L.; Colman, B.P.; McGill, B.M.; Wright, J.P.; Bernhardt, E.S. Effects of silver nanoparticle exposure on germination and early growth of eleven wetland plants. PLoS ONE 2012, 7, 47674. [CrossRef] [PubMed]

40. Mehrian, S.K.; Heidari, R.; Rahmani, F.; Najafi, S. Effect of chemical synthesis silver nanoparticles on germination indices and seedlings growth in seven varieties of Lycopersicon esculentum Mill (tomato) plants. J. Clust. Sci. 2016, 27, 327-340. [CrossRef]

41. Das, P.; Barua, S.; Sarkar, S.; Karak, N.; Bhattacharyya, P.; Raza, N.; Bhattacharya, S. Plant extract-mediated green silver nanoparticles: Efficacy as soil conditioner and plant growth promoter. J. Hazard. Mater. 2018, 346, 62-72. [CrossRef]

42. Barbasz, A.; Kreczmer, B.; Oćwieja, M. Effects of exposure of callus cells of two wheat varieties to silver nanoparticles and silver salt $\left(\mathrm{AgNO}_{3}\right)$. Acta Physiol. Plant. 2016, 38, 76. [CrossRef]

43. Lee, W.M.; Kwak, J.I.; An, Y.J. Effect of silver nanoparticles in crop plants Phaseolus radiatus and Sorghum bicolor: Media effect on phytotoxicity. Chemosphere 2012, 86, 491-499. [CrossRef] [PubMed]

44. Syu, Y.Y.; Hung, J.H.; Chen, J.C.; Chuang, H.W. Impacts of size and shape of silver nanoparticles on Arabidopsis plant growth and gene expression. Plant Physiol. Biochem. 2014, 83, 57-64. [CrossRef] [PubMed]

45. Krishnaraj, C.; Jagan, E.G.; Ramachandran, R.; Abirami, S.M.; Mohan, N.; Kalaichelvan, P.T. Effect of biologically synthesized silver nanoparticles on Bacopa monnieri (Linn.) Wettst. plant growth metabolism. Process Biochem. 2012, 47, 651-658. [CrossRef]

46. Calabrese, E.J.; Blain, R.B. Hormesis and plant biology. Environ. Pollut. 2009, 157, 42-48. [CrossRef] [PubMed]

47. Juárez-Maldonado, A.; Ortega-Ortíz, H.; Morales-Díaz, A.; González-Morales, S.; Morelos-Moreno, Á.; Sandoval-Rangel, A.; Cadenas-Pliego, G.; Benavides-Mendoza, A. Nanoparticles and nanomaterials as plant biostimulants. Int. J. Mol. Sci. 2019, 20, 162. [CrossRef] [PubMed]

48. Mohamed, A.K.S.; Qayyum, M.F.; Abdel-Hadi, A.M.; Rehman, R.A.; Ali, S.; Rizwan, M. Interactive effect of salinity and silver nanoparticles on photosynthetic and biochemical parameters of wheat. Arch. Agron. Soil Sci. 2017, 63, 1736-1747. [CrossRef]

49. Iqbal, M.; Raja, N.I.; Hussain, M.; Ejaz, M.; Yasmeen, F. Effect of silver nanoparticles on growth of wheat under heat stress. Iran J. Sci. Technol. A 2019, 43, 387-395. [CrossRef] 
50. Morales, M.I.; Rico, C.M.; Hernandez-Viezcas, J.A.; Nunez, J.E.; Barrios, A.C.; Tafoya, A.; Flores-Marges, J.P.; Peralta-Videa, J.R.; Gardea-Torresdey, J.L. Toxicity assessment of cerium oxide nanoparticles in cilantro (Coriandrum sativum L.) plants grown in organic soil. J. Agric. Food Chem. 2013, 61, 6224-6230. [CrossRef] [PubMed]

51. Bakshi, M.; Liné, C.; Bedolla, D.E.; Stein, R.J.; Kaegi, R.; Sarret, G.; Pradas Del Real, A.E.; Castillo-Michel, H.; Abhilash, P.C.; Larue, C. Assessing the impacts of sewage sludge amendment containing nano- $\mathrm{TiO}_{2}$ on tomato plants: A life cycle study. J. Hazard. Mater. 2019, 369, 191-198. [CrossRef] [PubMed]

(C) 2019 by the authors. Licensee MDPI, Basel, Switzerland. This article is an open access article distributed under the terms and conditions of the Creative Commons Attribution (CC BY) license (http://creativecommons.org/licenses/by/4.0/). 